\title{
Determinants of Employee's Research Productivity in Non-Academic Organizations and Building and Validating a Self-Assessment Tool
}

\author{
Nabeel Al Amiri (Corresponding author) \\ Tawam Hospital, Al Ain, UAE \\ ORCID iD: https://orcid.org/0000-0003-4446-1637 \\ E-mail: alamirinabeel@hotmail.com \\ Khaled Al Qawasmeh \\ Tawam Hospital, Al Ain, UAE \\ ORCID iD https://orcid.org/0000-0002-8965-6529
}

Received: July 19, 2021 Accepted: August 20, 2021 Published: September 3, 2021

doi:10.5296/ijld.v11i3.18661ＵRL: https://doi.org/10.5296/ijld.v11i3.18661

\begin{abstract}
Research is a systematic approach to answering evolving inquiries and creating new knowledge critical for organizational development, competitiveness, and innovation. This study aimed to identify the determinants that affect employee individual research productivity. And to create a reliable and valid measurement tool to assist organizations in identifying employees who are ready to produce research. The authors conducted a comprehensive literature review about the topic, illustrated the relationship between the relevant variables in a model, and tested the tool quantitatively on a sample of 161 nurses at a tertiary hospital in the UAE. The analysis revealed that integration of self-efficacy and self-determination plays a critical role in individual research productivity in non-academic organizations. The study also came up with a reliable and valid tool.
\end{abstract}

Keywords: research, research productivity, organization, individual readiness, self-efficacy, self-determination, motivation

\section{Introduction}

Research has a critical role in making changes in the life of humans and developing the entire 
world. For example, researchers have changed the world by spawning new industries, making businesses more productive, enabling faster communication and transportation, and helping people live longer and healthier (Joint Economic Committee - US Congress, 2014). Ezell and Andes (2016) claimed that the government and business investments in basic and applied research and development (R\&D) establish the foundation for developing future technologies, products, firms, and industries. For example, businesses in the USA accounted for $63 \%$ of all research and development expenditures, $30 \%$ from the federal government, and $7 \%$ from state and local governments, nonprofits, and universities. While the remaining came from other sources (National Center for Science and Engineering Statistics (NCSES), 2013).

Nevertheless, organizational research productivity is still low in many countries, particularly in developing countries that expend less on research and development (R\&D), as reported by the UNESCO Institute for Statistics (2020), due to a lack of organizational support as well as to individual factors, such as lack of knowledge and skills. To fill the gaps, some organizations implement various strategies to prepare a capable workforce. Those strategies include building a research culture in the organization, providing training, incentives, and funds to employees.

Accordingly, the authors argue that governments and organizations should invest in research and development and prepare a capable workforce to meet the future needs of organizations and contribute to economic growth. The authors also argue that organizations should focus their efforts on employees who are ready to adopt new behaviors toward participation in the organizational research activities that need a high level of knowledge, skills, and tolerance rather than starting with extensive efforts on supporting and training all employees, including those who are not ready. Focusing on employees ready for research could help organizations to get an immediate win.

In consequence, this study aimed to identify the determinants that affect the employee individual research productivity. And create a reliable and valid measurement tool to assist organizations to identify employees who have a high level of readiness to produce research. The authors conducted a comprehensive literature review about the topic, summarized the relevant variables related to non-academic context, illustrated the relationship between all variables in a model, and built a tool to measure those relationships. More, the authors examined the tool quantitatively on employees working in a tertiary hospital in the UAE. Lastly, the authors conducted a confirmatory factor analysis to confirm the validity.

\section{Literature Review}

\subsection{Research in Organizations}

One important debate is that academic research has fewer benefits for solving practical problems in organizations as academic scholars put their knowledge into theoretical knowledge rather than practice. According to Van de Ven (2005), this debate encourages organizations to do more practical research.

Swanson (2005) claimed that studying people, information flow, power, external economic forces, and other aspects of the organizations is challenging as organizations are complex, 


\section{Al Macrothink}

International Journal of Learning and Development

ISSN 2164-4063

2021, Vol. 11, No. 3

open, and dynamic systems. Therefore, scholars need to use multiple inquiry methods to investigate many research-based questions and a wide range of phenomena that exceeds any single research method.

Ghaffar and Khan (2014) found a positive correlation between research and development ( $\mathrm{R}$ $\&$ D) and the firm performance through improving the ratio of return on assets (ROA), the ratio of return on equity (ROE), and the earnings per share of the firm (EPS). More, Ulla (2018) recognized some benefits of doing classroom-based research for their teaching practices and career development and highlighted some challenges of doing research, including the lack of financial support, heavy teaching load, lack of research skills and knowledge, and lack of research materials and resources.

\subsection{Individual Research Factors}

Mantikayan and Abdulgani (2018) found four critical factors that influence faculty research productivity. Those factors include individual factors, institutional factors, leadership factors, and ascriptive factors. Furthermore, Heng, Hamid, and Khan (2020) identified individual factors, institutional factors, and national factors, such as policies and freedom as the main factors affecting scholars' research engagement and productivity. The authors reviewed and summarized thirteen papers, which are related to individual research productivity. Table 1 summarizes several individual variables identified in the literature as having roles in enhancing individual research productivity. Table 1 summarizes several individual variables identified in the literature as having roles in enhancing individual research productivity.

Table 1. Individual factors, which enhance research productivity

\begin{tabular}{|c|c|c|}
\hline Author and year & Method and Sample & Construct \\
\hline $\begin{array}{l}\text { Dakik, Kaidbey, and } \\
\text { Sabra, } 2006\end{array}$ & $\begin{array}{l}\text { - Quantitative } \\
\text { - Academics }\end{array}$ & Newly recruited faculty members \\
\hline $\begin{array}{l}\text { Wichian, } \\
\text { Wongwanich, and } \\
\text { Bowarnkitiwong, } \\
2009\end{array}$ & $\begin{array}{l}\text { - Quantitative } \\
\text { - Academics }\end{array}$ & $\begin{array}{l}\text { The researcher's characteristics include age, academic } \\
\text { position, research competence, skills and technique, } \\
\text { funding skills, research management, research } \\
\text { communication skills, networking, and teamwork. }\end{array}$ \\
\hline $\begin{array}{l}\text { Isfandyari-Moghadda } \\
\text { m, Hasanzadeh, and } \\
\text { Ghayoori, } 2012\end{array}$ & $\begin{array}{l}\text { - Quantitative } \\
\text { - Academic women }\end{array}$ & $\begin{array}{l}\text { Getting promoted in scientific rank, intrinsic talents, } \\
\text { perseverance, and adventitious knowledge, feeling of } \\
\text { being useful in society, getting promoted in the job, being } \\
\text { encouraged by friends and family, religious lessons } \\
\text { regarding the importance of science, and attempt to show } \\
\text { individual capabilities. }\end{array}$ \\
\hline
\end{tabular}


Bay and Clerigo, - Quantitative Research confidence with the technical aspect of writing 2013 Academics research.

- Mixed-methods

Nguyen, 2015

- Academics
Being young, being male, being at a high academic rank, obtaining a doctoral degree, having a low teaching load, attending frequent and good professional meetings, working in a department that has a positive research climate, receiving sufficient research funding for research projects, and publications, being able to access sufficient scholarly resources, receiving a higher salary than the current level, being able to access sufficient research infrastructure, and being satisfied with the university's research policy. Fursov, Roschina,
and Balmush, $2016 \quad$ Quantitative
- Academics

- $\quad$ Literature review

Aydin, 2017
The quality of scientific capital includes a diversity of research experience, socio-demographic characteristics, and direct economic stimuli.

Gender, age, tenure, academic rank, race, marital status, number of children, personal competence, personal confidence, to fulfill research responsibilities, analytic capacity, creative thinking, motivation, ambition, engagement as interest and involvement of research, working habits, research orientation, graduated Ph.D. program ranking and quality, years to complete the degree, dissertation subfield, research area, previous publication activity, communication with colleagues, belonging to a research team, number of supervised Ph.D. students, subscriptions to a large number of journals, and task orientation as disciplined management.

- Qualitative

Ulla, 2018

- Teachers

Personal motivation

Self-efficacy, affiliation, motivation, commitment,

Mantikayan and $\bullet \quad$ Systematic review

Abdulgani, 2018

- Academics orientation, basic and advanced research skills, sense of achievements, contributing to society, sense of responsibility, scholarly pursuit, autonomy and flexibility, and satisfying interest and curiosity. 
- Academics

- Quantitative

Ghabban et al., 2019 professional networking, years since Ph.D., and years of clinical and teaching experience.
Anamofa et al., 2019

- Quantitative

- Academics
Personal use of ICT

Research as the main task, research provides a solution, research results should be turned into articles, every written article should be published, research for new findings, research should be done at least once a year, feeling confident for the research in the area of expertise, feeling confident for collaboration, being able to write good articles, feeling confident to write articles, publication as scientific communication, understanding the criteria of publication, research for lecturer functional promotion, publications to be acknowledged by the public, research for financial gain, and research for famous.

Heng et al., 2020

- Literature review

- Academics
Age, research collaboration, gender, proficiency in English, academic rank, research orientation, academic degree, motivation, research knowledge and skills, research self-efficacy, academic discipline, desire for recognition and achievement, and time spent on research

Although literature highlighted several factors that affect individual research productivity, Wichian et al. (2009) underlined that research competence has more influence than the researcher characteristics and more influence than the institutional support on individual research productivity. Fursov et al. (2016) also demonstrated that the quality of research experience has a stronger impact on research productivity than the socio-demographic characteristics and the direct economic stimuli have a weak correlation with research productivity.

The literature review also identified some psychological theories that influence human performance. Bandura (1994) proposed the self-efficacy theory, which defines self-efficacy as people's beliefs about their capabilities to produce designated levels of performance that exercise their influence over events. Bandura $(1994,1977)$ underlined that self-efficacy affects people functioning through four psychological processes. First, it affects people's cognitive processes to set challenging goals, visualize the future, predict events, control them, and test and revise their actions, second, it affects people's motivational processes to spend a higher level of effort in the face of difficulties and improve their resilience to failures, third, it affects people's affective processes regarding controlling disturbing thoughts that, in turn, determine the level of stress they experience in difficult situations, and fourth, it affects 
people's selection process, for example, the ability to create beneficial environments and control their activities.

Desplaces (2005) linked the organizational change to people's readiness to adopt new behaviors, and self-efficacy plays a role in this relationship. Ahmadi (2020) also found that academic self-efficacy has a mediating role between self-esteem and academic achievement. Some literature disclosed a link between the self-efficacy theory and student's performance and academic achievements (Basith, Syahputra, and Ichwanto, 2020; Köseoğlu, 2015; Ahmad and Safaria, 2013). Also, the literature disclosed a link between the self-efficacy theory and student's performance and academic achievements (Basith, Syahputra, and Ichwanto, 2020; Köseoğlu, 2015; Ahmad and Safaria, 2013).

On the other hand, Deci and Ryan (2015) proposed the self-determination theory as a motivational theory of personality, development, and social processes that examines how social contexts and individual differences facilitate different types of motivation, including autonomous motivation and controlled motivation, and in turn predict learning, performance, experience, and psychological health. More the self-determination theory proposes that all human beings have three basic psychological needs that are competence, autonomy, and relatedness for effective functioning and wellness (Deci and Ryan, 2015). Deci and Ryan (2008) argued that the type of motivation is more important than the amount for predicting effective performance. They underlined two types of motivation. First, autonomous motivation includes intrinsic motivation, and extrinsic motivation for a particular activity is integrated into the sense of self as having a specific value, and second, is the controlled motivation, which includes external regulation responding to external contingencies of reward or punishment, and introjected regulation responding to other factors such as an approval motive, avoidance of shame, contingent self-esteem, and ego-involvements. Ryan and Deci (2000) claimed that social conditions that support one's feelings of competence, autonomy, and relatedness are the basis for maintaining intrinsic motivation and becoming more self-determined for extrinsic motivation.

The literature review also disclosed evidence for the integration of self-determination theory and self-efficacy theory. Sweet, Fortier, Strachan, and Blanchard (2012) discovered that self-determined motivation and confidence were significant predictors of physical activity. Nevertheless, they recommended future research to understand further the integration between the two theories. Irvine (2018) proposed a model to compare several psychological theories. He placed self-efficacy, which is based mainly on the self-perception of the individual capabilities without including any value judgment about the importance of the task or subject in the expectancy-intrinsic quadrant, while the self-determination theory is placed mainly in the intrinsic-value quadrant (Fig. 1). Some theories, such as the achievement goal theory, are excluded from this review as those theories focus on performance more than readiness and extrinsic environment rather than intrinsic factors. However, the model, according to the author, is not perfect. 


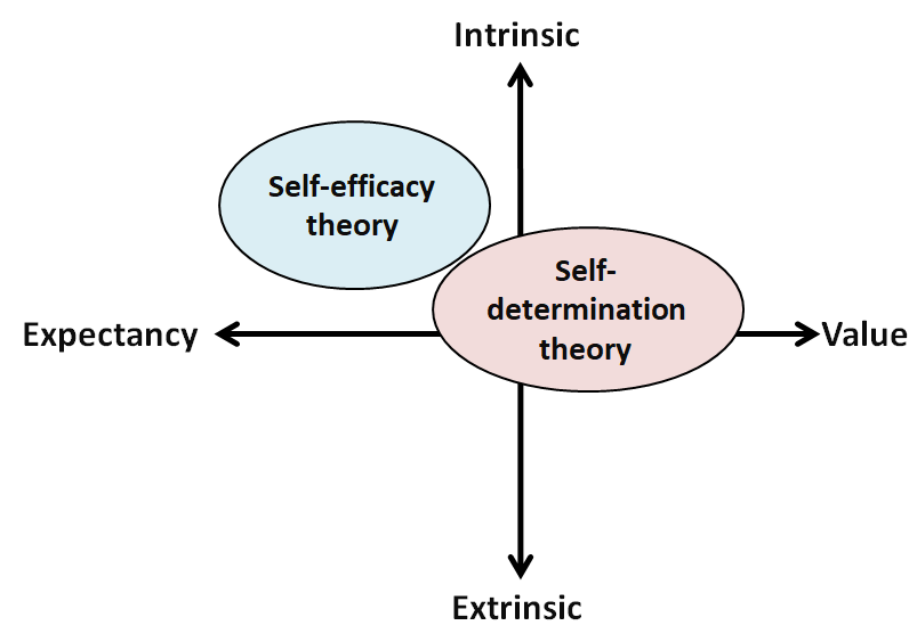

Figure 1. Axes for comparing self-efficacy theory and self-determination theory as proposed by Irvine (2018)

\section{The Theoretical Model of the Study}

Individual readiness is defined by LEXICO (n.d.) as "the state of being fully prepared for something", "willingness to do something", and "the quality of being immediate, quick, or prompt." The authors examined critically all factors listed in table 1 to identify the factors that could determine the status of individual readiness for research productivity and find the common themes among those variables. Then, the authors classified those variables into five groups.

The first group that includes the socio-demographic characteristics is excluded from this study as it has less influence on individual research productivity (Fursov et al., 2016; Wichian et al., 2009). The second group includes extrinsic factors, such as popularity, financial gain, and promotion and promotion that have a weak correlation with research productivity (Fursov et al., 2016; Wichian et al., 2009). The third group includes factors related more to the organization, including positive research climate, sufficient research funding, sufficient scholarly resources, sufficient research infrastructure, subscriptions to a large number of journals, and research policy, are excluded from this study as those factors are not within the scope of the study. The fourth group includes factors related to universities and academic field, including affiliation, scholarly pursuit, academic rank, academic discipline/area, newly recruited faculty members, number of supervised Ph.D. students, having a low teaching load, research as the main task, faculty-student collaboration, years since Ph.D., years of clinical and teaching experience, and working habits, is also excluded as it is only suitable for academic ad university context. The fifth group includes variables, which are general and suitable for various contexts such as manufacturing, healthcare, and others. Also, those factors are found related to two famous theories; the self-efficacy theory and the self-determination theory (Table 2). 


\section{Macrothink}

International Journal of Learning and Development

ISSN 2164-4063 2021, Vol. 11, No. 3

Table 2. Individual factors found general for research productivity in various contexts

\begin{tabular}{|c|c|c|c|}
\hline \multicolumn{2}{|l|}{ Construct } & Sub-construct & Frequency \\
\hline \multirow{2}{*}{\multicolumn{2}{|c|}{ Self-efficacy theory }} & Self-efficacy & 2 \\
\hline & & Personal confidence & 2 \\
\hline \multirow{17}{*}{$\begin{array}{l}\text { Self-determination } \\
\text { theory }\end{array}$} & \multirow{13}{*}{ Intrinsic motivation } & Motivation & 3 \\
\hline & & Ambition & 1 \\
\hline & & Orientation & 4 \\
\hline & & Interest and curiosity & 2 \\
\hline & & Sense of achievements & 3 \\
\hline & & Contributing to society & 1 \\
\hline & & Research for new findings & 1 \\
\hline & & Sense of responsibility & 2 \\
\hline & & Research should be done yearly & 1 \\
\hline & & Publication & 1 \\
\hline & & Research provides a solution & 1 \\
\hline & & Obtaining academic degree & 3 \\
\hline & & Commitment & 1 \\
\hline & Extrinsic motivation & Religious lessons about science & 1 \\
\hline & \multirow{3}{*}{ Competence } & Human capital & 1 \\
\hline & & Analytic capacity & 1 \\
\hline & & Creative thinking & 1 \\
\hline
\end{tabular}




\begin{tabular}{|c|c|c|}
\hline & Research knowledge and skills & 8 \\
\hline & Proficiency in English & 1 \\
\hline & Personal use of ICT & 1 \\
\hline & Previous research experience & 2 \\
\hline & Intrinsic talent & 1 \\
\hline & Manage time spent on research & 1 \\
\hline Autonomy & Autonomy and flexibility & 1 \\
\hline & Social capital & 1 \\
\hline & Belonging to a research team & 2 \\
\hline & Research collaboration & 2 \\
\hline relatedness & $\begin{array}{l}\text { Attending frequent } \quad \text { professional } \\
\text { meetings }\end{array}$ & 1 \\
\hline
\end{tabular}

Communication with colleagues

1

Encouraged by friends and family

1

In consequence, Table 2 confirms that the individual readiness, or the state of being fully prepared, willing, and being immediate and quick, to produce research is connected to the integration of well-known psychological theories that are the self-efficacy and self-determination theories. Accordingly, employees with higher levels of self-efficacy and self-determination are more prone to produce researches than others. Additionally, the authors examined the relationship of self-efficacy and the self-determined theory as recommended by Sweet et al. (2012) by proposing that self-efficacy is a predictor of self-determination (Fig. 2) based on Bandura (1994, 1977) description of self-efficacy as affecting people functioning, motivational processes, affective processes, and creating beneficial environments and control their activities.

To build a scale that assesses employee's readiness to conduct researches, the authors followed the steps follows: 1) identifying the theoretical constructs based on the literature review, 2) creation of the sale items, considering that each item presents one diminution, 


\section{Macrothink}

International Journal of Learning and Development

ISSN 2164-4063 2021, Vol. 11, No. 3

simple, short, and clear, 3) grouping the items into sub-groups guided by the main constructs, 4) reviewing the final scale to ensure consistency, 5) distribution of the survey, and 6) analyzing the data including factor analysis, internal consistency assessment, construct validation, including convergent and discriminant validity, Adjusted Goodness of Fit Index, and confirmatory factor analysis.

\section{Individual Readiness}

\section{Self-Efficacy}

\section{Self-Determination}

Figure 2. A model illustrates the relationship between self-efficacy and self-determination

\section{Purpose of the Study}

The study aimed to assist organizations in identifying employees who have a high level of readiness to produce researches. The sub-goals include:

- To identify the determinants of individual research productivity of employees in non-academic organizations.

- To build a self-assessment tool to assists in identifying employees who have the readiness to conduct researches in organizations based on the literature review.

- To confirm the reliability and validity of the tool, including the items and constructs.

- To identify the relationship between the various constructs.

\section{The Significance of the Study}

The study could come up with a reliable and valid tool. The tool may assist organizations in identifying employees who are ready to conduct research. Accordingly, organizations could plan and implement a focused and effective research development program for those employees.

This approach could end with a win-to-win situation for employees and the organization; the employees will develop their research knowledge and skills, and the organizations will get opportunities for development and innovation.

\section{Methodology}

The study used a quantitative, cross-sectional design, which is commonly used to validate research tools. The cross-sectional design has advantages, including it requires a short time 


\section{Macrothink}

and fewer resources to collect the necessary data by distributing a survey. Hence, the authors prepared a survey that contained two parts; the first part included 20 items with a 5 point Likert scale, which included 1 (strongly disagree), 2 (disagree), 3 (not sure), 4 (agree), and 5 (strongly agree); the second part collected demographic data about age, gender, education, position, unit, and workplace.

In more detail, the authors adopted the self-efficacy theory (Bandura, 1994) to build the survey, including people's beliefs about their capabilities to produce researches (items 1 and 2) and their beliefs about their influence over events (items 3 and 4). The authors also adopted the self-determination theory (Deci and Ryan, 2015; Ryan and Deci, 2000), including motivation, i.e., orientation (items 5 and 6), sense of responsibility (item 7), sense of achievement (item 8), interest (item 9), and ambition (item 10), competence (item11, 12, 13, 14, 15, and 16), autonomy (item 17 and 18), and psychological relatedness (item 19 and 20) as constructs and sub-constructs of the study.

The authors selected nurses working at a tertiary hospital in UAE as the population for this study. The concerned nurses were well-known for their low research productivity. On the other hand, no adequate information is available about their readiness to conduct research.

The authors distributed the assessment tool via emails containing a link to all nurses working (whole sample technique) in a tertiary hospital in the UAE. The authors collected the responses from participants over one month and sent reminder emails to the targeted sample in the second and third weeks. The authors used the Smart-PLS 3 for data analysis.

\section{Results}

The final analysis procedure has included 161 responses. The analysis shows that the responders present different ages, genders, degrees, positions, units, and experiences. The demographic data analysis illustrated that most of the respondents are between 31 and 50 years old, females, staff nurses, holding bachelor degrees, working in inpatients wards and out-patient clinics, and with experiences between 6 and 15 years. See Table 3 for details. 
Table 3. Demographic profile of the respondents

\begin{tabular}{|c|c|c|c|c|}
\hline Category & Sub-categories & Frequency & Percent & Cumulative Percent \\
\hline \multirow[t]{4}{*}{ Age } & $24-30$ years & 18 & 11.2 & 11.2 \\
\hline & $31-40$ years & 79 & 49.1 & 60.2 \\
\hline & $41-50$ years & 42 & 26.1 & 86.3 \\
\hline & More than 50 years & 22 & 13.7 & 100.0 \\
\hline \multirow[t]{2}{*}{ Gender } & Male & 29 & 18.0 & 18.0 \\
\hline & Female & 132 & 82.0 & 82.0 \\
\hline \multirow[t]{7}{*}{ Position } & Practical Nurse & 13 & 8.1 & 8.1 \\
\hline & Staff Nurse & 103 & 64.0 & 72.1 \\
\hline & Charge Nurse & 22 & 13.7 & 85.8 \\
\hline & Unit Manager & 16 & 9.9 & 95.7 \\
\hline & Clinical Resource Nurse & 3 & 1.9 & 97.6 \\
\hline & ADON/DON & 0 & 0 & 97.6 \\
\hline & Others & 4 & 2.5 & 100 \\
\hline \multirow[t]{4}{*}{ Education } & Diploma & 25 & 15.5 & 15.5 \\
\hline & Bachelor & 110 & 68.3 & 83.8 \\
\hline & Master & 24 & 14.9 & 98.7 \\
\hline & Ph.D. & 2 & 1.2 & 100 \\
\hline \multirow[t]{6}{*}{ Unit } & Day case & 2 & 1.2 & 1.2 \\
\hline & ER & 7 & 4.3 & 5.6 \\
\hline & Inpatient & 62 & 38.5 & 44.1 \\
\hline & OR & 2 & 1.2 & 45.3 \\
\hline & Other & 33 & 20.5 & 65.8 \\
\hline & Outpatient & 55 & 34.2 & 100.0 \\
\hline \multirow[t]{5}{*}{ Experience } & $1-5$ years & 14 & 8.7 & 8.7 \\
\hline & 6-10 years & 44 & 27.3 & 36 \\
\hline & $11-15$ years & 43 & 26.7 & 62.7 \\
\hline & $16-20$ years & 21 & 13.0 & 75.7 \\
\hline & Above 20 years & 39 & 24.2 & 100 \\
\hline Total & & 161 & 100.0 & 100 \\
\hline
\end{tabular}




\section{Al Macrothink}

International Journal of Learning and Development

ISSN 2164-4063

2021, Vol. 11, No. 3

The descriptive analysis of responses, which enables us to compare the outcome of various variable, present that all the means of all variables fall in the range of 3 to 4.1 and all the scores fall within 0.8 to 1.3 standard deviation of the mean (Table 4).

Table 4. Descriptive analysis of responses

\begin{tabular}{|c|c|c|c|c|}
\hline & & Mean & SD & Variance \\
\hline 1 & I am confident that I have basic research knowledge and skills. & 3.658 & .923 & .851 \\
\hline 2 & I am confident that I can complete a research project. & 3.571 & .899 & .809 \\
\hline 3 & I can stand against all possible challenges related to conducting research. & 3.528 & .867 & .751 \\
\hline 4 & I can learn what is needed to conduct research. & 3.832 & .838 & .703 \\
\hline 5 & I believe that research provides new solutions. & 4.161 & .843 & .711 \\
\hline 6 & I believe that research builds my credibility. & 3.994 & .840 & .706 \\
\hline 7 & I feel responsible for producing research. & 3.677 & .878 & .770 \\
\hline 8 & I feel proud of participating in research activities. & 3.994 & .855 & .731 \\
\hline 9 & I have the interest to reach new findings. & 3.932 & .9228 & .852 \\
\hline 10 & I am enthusiastic about participating in a research project. & 3.820 & .880 & .774 \\
\hline 11 & 1I master the skills of formulating research problems and questions. & 3.373 & .941 & .885 \\
\hline 12 & I master the skills of searching for information online. & 3.509 & .950 & .901 \\
\hline 13 & I master the skills of academic writing. & 3.329 & .893 & .797 \\
\hline 14 & I have basic knowledge of the various research methodologies. & 3.236 & .863 & .744 \\
\hline 15 & I master the basic skills of analyzing data. & 3.149 & .930 & .865 \\
\hline 16 & I have previous research experience. & 3.087 & 1.247 & 1.555 \\
\hline 17 & I have a sense of academic independence. & 3.422 & .885 & .783 \\
\hline 18 & I can develop my research knowledge and skills alone. & 3.062 & 1.011 & 1.021 \\
\hline 19 & I am willing to participate in long-run research learning activities. & 3.565 & .927 & .860 \\
\hline 20 & I have the intention to join a research team. & 3.634 & .913 & .834 \\
\hline
\end{tabular}

For the analysis of the measurement model, the authors calculated the convergent validity, including factor loading and the construct-level reliability (i.e., composite reliability and the Cronbach's $\alpha$ ), the construct discriminant validity (i.e., the Average Variance Extracted 
(AVE)), as well the Goodness of Fitness (GoF). Table 5 shows that most of the factors loading results are acceptable as they are higher than 0.7 except for item 16 that is very close to 7 . Furthermore, the composite reliability results are higher than 0.7 , and the Cronbach's alpha results are more than the recommended value of 0.7 for all scales reflecting a sufficient relationship among the items within the constructs. Table 5 also shows Average Variance Extracted (AVE) results above the recommended value of $0.5(50 \%)$, which indicates that every construct explains more than half of the variance to its measuring items on average.

Table 5. Internal consistency and convergence validity results

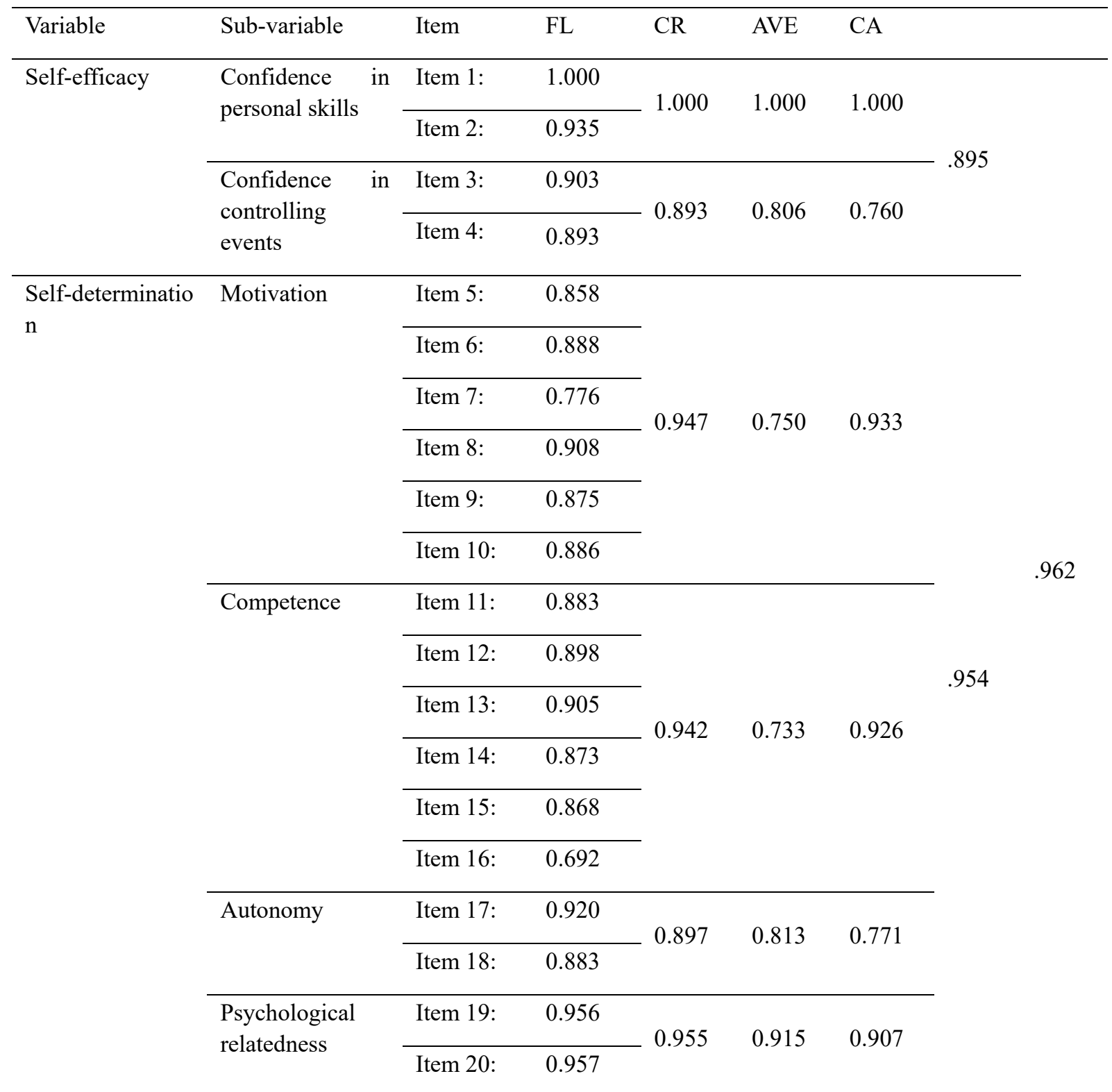

Notes. FL: Factor loading; CR: Composite Reliability; AVE: Average Variance Extracted; CA: Cronbach's Alpha. 


\section{Ml Macrothink}

International Journal of Learning and Development

ISSN 2164-4063

2021, Vol. 11, No. 3

To examine the discriminant validity, table 6 presents the results of the Heterotrait-Monotrait Ratio (HTMT), which reflects an actual distinctiveness of one construct from other constructs. The upper threshold value for the independent variables is 0.785 as highlighted in the bold boxes, which complies with the acceptable discriminant validity values of less than 0.90 . The authors deleted item 2 from the model to resolve a discriminant validity problem between the two independent variables. The analysis also reveals that no multicollinearity issue exists among the independent variables as the values of the Variance Inflation Factor (VIF) are 1.00 for self-efficacy and 1.885 for confidence in personal skills and confidence in controlling events, which are within the normal range of 1 to 5 .

Table 6. Results of Heterotrait-Monotrait Ratio (HTMT)

\begin{tabular}{|c|c|c|c|c|c|c|c|c|}
\hline 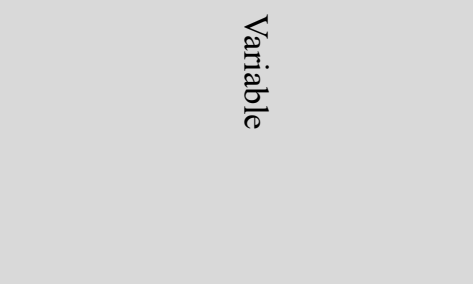 & 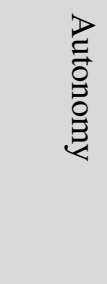 & $\begin{array}{l}\Omega \\
\stackrel{0}{B} \\
\frac{0}{0} \\
\stackrel{0}{0} \\
\stackrel{0}{8}\end{array}$ & 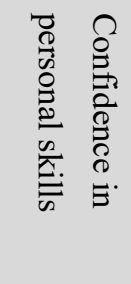 & 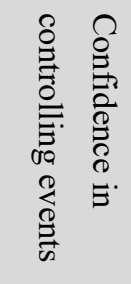 & 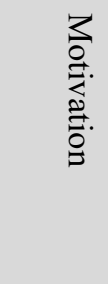 & 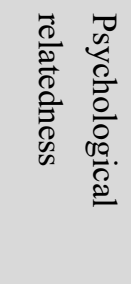 & 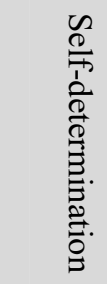 & 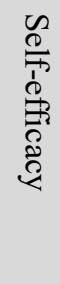 \\
\hline \multicolumn{9}{|l|}{ Autonomy } \\
\hline Competence & 0.992 & & & & & & & \\
\hline Confidence in personal skills & 0.714 & 0.744 & & & & & & \\
\hline Confidence in controlling events & 0.774 & 0.846 & 0.785 & & & & & \\
\hline Motivation & 0.606 & 0.695 & 0.534 & 0.938 & & & & \\
\hline Psychological relatedness & 0.782 & 0.738 & 0.44 & 0.716 & 0.767 & & & \\
\hline Self-determination & 0.95 & 0.976 & 0.689 & 0.949 & 0.928 & 0.893 & & \\
\hline Self-efficacy & 0.819 & 0.88 & 0.948 & 1.21 & 0.852 & 0.664 & 0.926 & \\
\hline
\end{tabular}

Furthermore, the results of the root mean square residual (SRMR) is used to report the goodness of fit $(\mathrm{GoF})$. The SRMR results are 0.118 for the saturated report and 0.125 for the estimated model. However, the result is slightly above the acceptable value of 0.1 , the highest margin of the normal value, the GoF analysis in Smart-PLS analysis is weak in confirming the fitness of proposed models. Thus, it is recommended to consider the path coefficients to decide how to modify the model.

For the analysis of the structure model analysis, the authors calculated the coefficient of determination (R2), effect size (f2), predictive relevance (Q2 value), and the confirmatory factor analysis (path coefficient). The R-square result for the variance explained by the endogenous construct (self-determination) is substantial as it is $0.673(>0.25)$, the $\mathrm{f} 2$ result of 


\section{Macrothink}

International Journal of Learning and Development

ISSN 2164-4063 2021, Vol. 11, No. 3

the endogenous constructs (self-determination) is large as it is $2.061(>0.34)$, the results of Q2 of the path model are higher than Zero, which reflects an adequate fit and high predictive relevance of the endogenous variables items (Table 7).

Table 7. Result of predictive relevance

\begin{tabular}{lccc}
\hline Endogenous Construct & SSO & SSE & Q $^{2}(=1-\mathrm{SSE} / \mathrm{SSO})$ \\
\hline Self-determination & 2576 & 1551.683 & 0.398 \\
\hline Self-efficacy & 483 & 127.422 & 0.736 \\
\hline
\end{tabular}

Concerning the relationships between the variables, Table 8 presents the results of the direct effect analysis (path coefficient), standards deviations, t-values, and p-values (fig. 3). Table 11 confirms that the path coefficient assessment results for all the relationships between the variables are significant at the level of 0.01 as all $\mathrm{p}$-values are less than 0.01 and $\mathrm{t}$-values more than 1.96. All relationships have positive directions.

Table 8. Path coefficient results

\begin{tabular}{|c|c|c|c|c|c|}
\hline & Std. $\beta$ & SD & T-value & P-value & Results \\
\hline Confidence in personal skills -> Self-efficacy & 0.377 & 0.012 & 32.491 & 0 & Significant, + \\
\hline $\begin{array}{l}\text { Confidence in controlling events } \quad-> \\
\text { Self-efficacy }\end{array}$ & 0.703 & 0.021 & 33.531 & 0 & Significant, + \\
\hline Self-efficacy -> Self-determination & 0.821 & 0.035 & 23.492 & 0 & Significant, + \\
\hline Self-determination -> Autonomy & 0.821 & 0.029 & 28.693 & 0 & Significant, + \\
\hline Self- determination $->$ Competence & 0.923 & 0.011 & 81.014 & 0 & Significant, + \\
\hline Self- determination -> Motivation & 0.873 & 0.019 & 46.583 & 0 & Significant, + \\
\hline $\begin{array}{l}\text { Self- determination } \quad->\text { Psychological } \\
\text { relatedness }\end{array}$ & 0.834 & 0.03 & 28.059 & 0 & Significant, + \\
\hline Self-efficacy -> Self-determination & 0.821 & 0.035 & 23.492 & 0 & Significant, + \\
\hline
\end{tabular}

Significant: $\mathrm{p}<0.01$. 


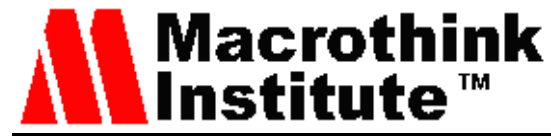

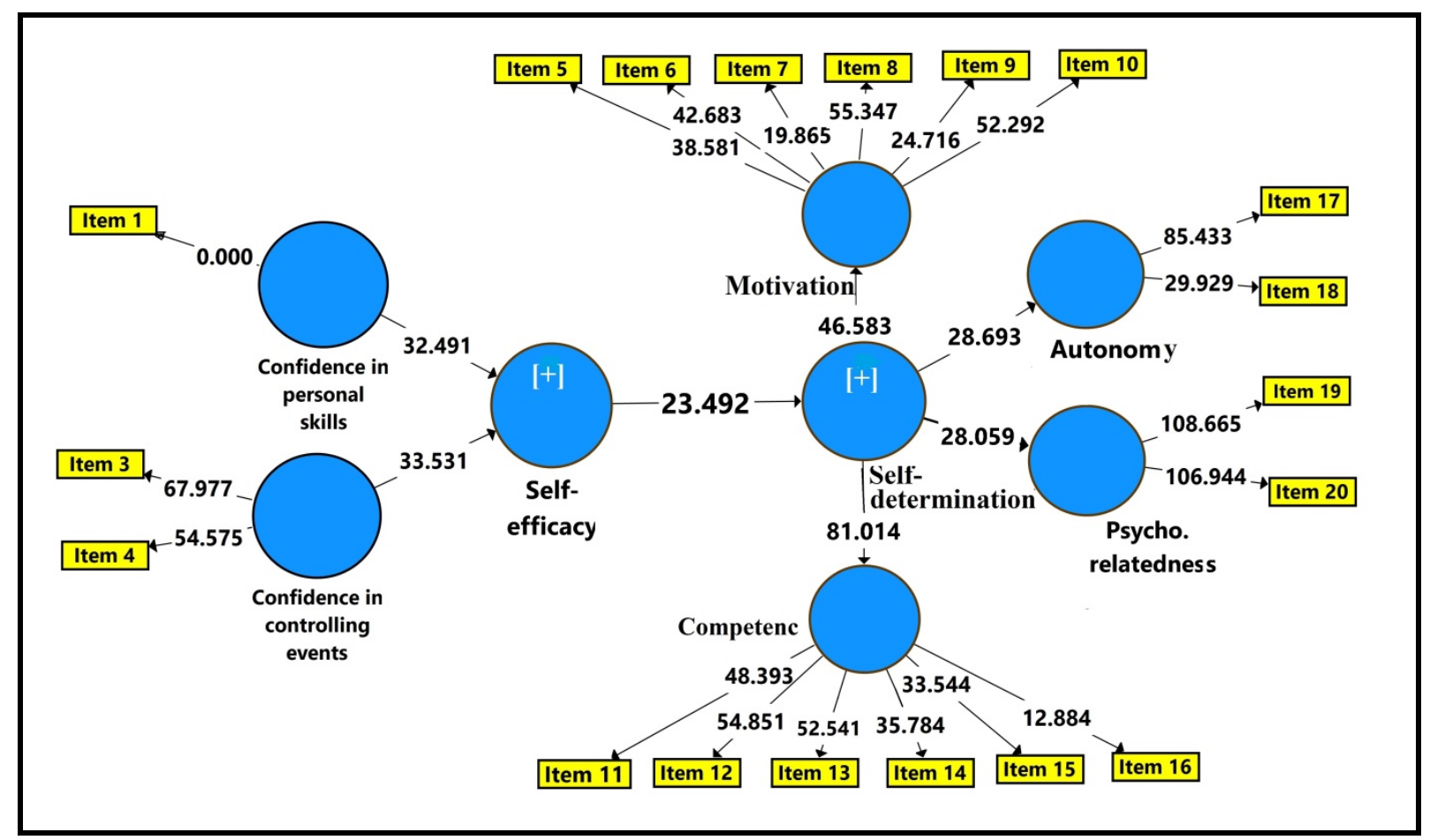

Figure 3. Structural Model with t-values (Bootstrapping result)

\section{Discussion}

The literature underlined that research productivity was studied mainly among scholars in higher education institutes. Scholars produce mainly researches that fill theoretical gaps for many reasons, such as the academic position, academic rank, research competence and skills, networking, personal confidence and motivation, and many others (Ulla, 2018, Aydin, 2017; Bay and Clerigo, 2013; Wichian, Wongwanich, and Bowarnkitiwong, 2009). On the contrary, the literature neglected to study employee's research productivity, which is relevant to solving practical problems in non-academic organizations.

Nevertheless, research is critical for organizational development, sustaining competitiveness, and innovation. Therefore, the authors argue that organizations should build their knowledge management capabilities, including creating a positive culture and providing necessary resources. The literature also highlighted that some specific individual factors are critical for enhancing research productivity. Accordingly, the authors argued that it is crucial to support employees ready to produce research, i.e., being prepared, willing, immediate, and quick. Thus, this study aimed to identify the determinants that affect the employee individual research productivity and create a reliable and valid measurement tool to assist organizations in identifying employees who have a high level of readiness to produce researches.

The literature review revealed that the individual readiness to produce research in non-academic organizations is mainly connected to the integration of well-known psychological theories that are the self-efficacy and self-determination theories. The 
self-efficacy dimensions include confidence in personal skills and confidence in controlling events (Bandura, 1994), and the self-determination dimensions include motivation, competence, autonomy, and psychological relatedness (Deci and Ryan, 2015; Ryan and Deci, 2000). More specifically, Wichian et al. (2009) underlined that research competence has more influence than the researcher characteristics and the institutional support on individual research productivity. The two theories guided the authors to prepare the study survey.

The analysis of the quantitative data revealed sufficient factor (items) loadings, and high construct-level reliability (i.e. composite reliability, AVE, and Cronbach's $\alpha$ ). The analysis also confirmed that the construct discriminant validity (i.e. HTMT and AVF) for the exogenous variables is within the normal range. For the endogenous variables, the analysis confirmed substantial $\mathrm{R}^{2}$, large effect size $\left(\mathrm{F}^{2}\right)$, and high predictive relevance $\left(\mathrm{Q}^{2}\right)$. Accordingly, the analysis confirmed the outer and inner reliability and validity of the survey. See appendix 1 for the final survey after deleting the redundant item (item 2).

Although the literature review did not provide a clear explanation for the relationship between self-efficacy and self-determination, the result of the study, particularly the CFA confirmed a significant positive predicting effect for self-efficacy on self-determination. Besides, the study found that self-efficacy and self-determination are highly correlated.

To enhance long-term research productivity in non-academic organizations, the authors encourage managers, project leaders, and educators to understand these two psychological theories and monitor the sub-dimensions, involving employee confidence, motivation, competence, autonomy, and psychological relatedness to maintain the high status of readiness among employees. Furthermore, the authors encourage organizations to prepare the required policies and procedures essential for research production and encourage cooperation and knowledge sharing among those employees by attending meetings or establish a concerned Community of Practice (CoP).

For employees who are not ready to produce research, organizations can adopt long-term psychological development and training. For example, to encourage employees to participate, give them frequent feedback, involve them in group activities, and share with them stories of success. For long-run success, non-academic organizations need to consider organizational factors such as the organizational culture, strategy, structure, education, human resources practices, such as performance appraisals and compensations, and providing resources, in addition to the individual factors.

\section{Conclusion}

In conclusion, the literature review highlighted the role of research in organizational development, competitiveness, and innovation, and identified also the critical role of individual factors in research productivity in organizations.

The study confirmed the integration of two famous theories, namely the self-efficacy and self-determination theories, in determining the individual readiness for research productivity, particularly in non-academic contexts. On the other hand, the study came up with a reliable and valid tool that can be used by non-academic organizations that seek to improve their 
research capabilities to identify employees who are ready to produce research. Identifying those employees could assist organizations in focusing their efforts and save resources.

\section{Limitations}

Most of the studies that the literature review found were relevant to the individual research productivity in higher education and universities as scholars did not study the individual research productivity in other contexts. Also, the study has other limitations, including using the cross-sectional design, which is limited in assessing the causal relationships, the limited size of the sample, and the responses collected from one hospital in the UAE, which could affect the generalizability of the findings.

The authors recommend conducting additional studies in various sectors and contexts to confirm the results of this study. The authors recommend considering the longitudinal research design in the scale development.

\section{Implications}

The study provides a tool to help business organizations to identify employees who are ready to produce research. The study could help managers understanding and maintaining a positive psychological status among employees, including high confidence, motivation, competence, autonomy, and relatedness toward research production. And suggests preparing the required policies and procedures essential for research production and encourage cooperation and knowledge sharing among those employees.

On the other hand, the study suggests adopting long-term psychological development and training for employees who are not ready to produce research. For example, the study suggests building organizational culture, strategy, structure, education system, human resources practices, e.g., performance appraisals and compensations, and providing resources.

\section{Declarations}

Availability of data and materials: The data that support the findings of this study are available on reasonable request from the corresponding author.

Conflict of interest: The authors declare that they have no conflict of interest

Funding: No funds were provided for this paper.

Ethical Consideration: This study was reviewed and approved by the Tawam Hospital Research Ethical Committee. The authors have adhered to the ethical research standards all the time, including protecting the participant's identity and the data.

\section{References}

Ahmad, A., \& Safaria, T. (2013). Effects of self-efficacy on students' academic performance, Journal of Educational, Health and Community Psychology, 2(1), 22-29. http://dx.doi.org/10.12928/jehcp.v2i1.3740

Ahmadi, S. (2020). Academic self-esteem, academic self-efficacy and academic achievement: 
a path analysis, Journal of Forensic Psychology, 5(155). https://doi.org/10.35248/2475-319X.19.5.155

Anamofa, J. N., Nanuru, R. F., Suhardi, S., Lekahena, V., Cahyono, T. D., Purimahua, S. Y., Khaeril, K., ... \& Latupapua, M. (2019). Factors influencing research productivity of private higher education institutions lecturers in Kopertis region XII, Proceedings of the 2nd International Conference on Advance and Scientific Innovation, ICASI. Banda Aceh, Indonesia, EAI

Aydin, O. T. (2017). Research performance of higher education institutions: a review on the measurements and affecting factors of research performance, Journal of Higher Education and Science, 7(2), 312-320. doi: 10.5961/jhes.2017.210

Bandura, A. (1977). Self-efficacy: Toward a unifying theory of behavioral change, Psychological Review, 84(2), 191-215. https://doi.org/10.1037/0033-295X.84.2.191

Bandura, A. (1994). Self-efficacy, in V. S. Ramachaudran (Ed.), Encyclopedia of human behavior, $\left(4^{\text {th }}\right.$ Ed., pp.71-81). Academic Press

Basith, A., Syahputra, A., \& Ichwanto, M. A. (2020). Academic self-efficacy as predictor of academic achievement, Jurnal Pendidikan Indonesia, 9(1), 163-170. doi: 10.23887/jpi-undiksha.v9i1.24403

Bay, B. E Jr., \& Clerigo, M. E. C. (2013). Factors associated with research productivity among oral healthcare educators in an Asian university, International Education Studies, 6(8), 124-135. http://dx.doi.org/10.5539/ies.v6n8p124

Dakik, H. A., Kaidbey, H., \& Sabra, R. (2006). Research productivity of the medical faculty at the American University of Beirut, Postgrad Med J., 82(969), 462-464. http://dx.doi.org/10.1136/pgmj.2005.042713

Deci, E. L. \& Ryan, R. M. (2008). Self-determination theory: a macro theory of human motivation, development, and health', Canadian Psychology, 49(3), 182-185. https://doi.org/10.1037/a0012801

Deci, E. L. \& Ryan, R. M. (2015). Self-determination theory, in James D. Wright (Eds.), International Encyclopedia of the Social \& Behavioral Sciences (2nd ed., pp.486-491). Elsevier Health Sciences. http://dx.doi.org/10.1016/B978-0-08-097086-8.26036-4

Desplaces, D. (2005). A multilevel approach to individual readiness to change, The Journal of Behavioral and Applied Management, 7(1), 25-39. https://doi.org/10.21818/001c.14568

Ezell, S. \& Andes, S. (2016). Localizing the economic impact of research and development: Fifty policy proposals for the Trump administration and Congress. Retrieved from https://www.brookings.edu/research/localizing-the-economic-impact-of-research-and-develop ment/

Fursov, K., Roschina, Y., \& Balmush, O. (2016). Determinants of research productivity: an individual-level lens, Foresight and STI Governance, 10(2), 44-56. 
http://dx.doi.org/10.17323/1995-459X.2016.2.44.56

Ghabban, F., Selamat, A., Ibrahim, R., Krejcar, O., Maresova, P., \& Herrera-Viedma, E. (2019). The influence of personal and organizational factors on researchers' attitudes towards sustainable research productivity in Saudi universities, Sustainability, 11(17), 4804. https://doi.org/10.3390/su11174804

Ghaffar, A. \& Khan, W. A. (2014). Impact of research and development on firm performance, International Journal of Accounting and Financial Reporting, 4(1), 357-367. https://doi.org/10.5296/ijafr.v4i1.6087

Heng, K., Hamid, M. O., \& Khan, A. (2020). Factors influencing academics' research engagement and productivity: A developing countries perspective, Issues in Educational Research, 30(3), 965-987. Retrieved from https://www.iier.org.au/iier30/heng.pdf

Irvine. J. (2018). A framework for comparing theories related to motivation in education, Research in Higher Education Journal, 35, 1-30. Retrieved from https://www.aabri.com/manuscripts/182835.pdf

Isfandyari-Moghaddam, A., Hasanzadeh, M., \& Ghayoori, Z. (2012). A study of factors affecting research productivity of Iranian women in ISI', Scientometrics, 91(1), 159-172. https://doi.org/10.1007/s11192-011-0585-5

Joint Economic Committee - US Congress (2014). The role of research \& development in strengthening America's innovation economy. Retrieved from https://www.jec.senate.gov/public/_cache/files/84a7d83c-fc1f-4316-a72e-087fb748d2e2/the-r ole-of-research-and-development.pdf

Köseoğlu, Y. (2015). Self-efficacy and academic achievement - a case from turkey, Journal of Education and Practice, 6(29), 131-141. Retrieved from https://www.iiste.org/Journals/index.php/JEP/article/view/26683/27333

LEXICO (n.d.). Readiness. Retrieved from https://www.lexico.com/definition/readiness

Mantikayan, J. M \& Abdulgani, M. A. (2018). Factors affecting faculty research productivity: conclusions from a critical review of the literature, JPAIR Multidisciplinary Research, 31(1). doi:10.7719/JPAIR.V31I1.561

National Center for Science and Engineering Statistics (NCSES) (2013). National patterns of $R \& D$ resources: 2011-12 data update. Retrieved from https://www.nsf.gov/statistics/nsf14304/pdf/nsf14304.pdf

Nguyen, Q. H. (2015). Factors Influencing the Research Productivity of Academics at the Research-Oriented University in Vietnam, School of Education and Professional Studies Arts, Education, and Law Group, Griffith University. https://doi.org/10.25904/1912/1578

Ramkumar, S. (2018). Faculty research productivity: perspective from human and social capital, Amity Journal of Management Research, 3(1), 81-94. Retrieved from https://amity.edu/UserFiles/admaa/ae762Paper\%207.pdf 


\section{Macrothink}

International Journal of Learning and Development

ISSN 2164-4063 2021, Vol. 11, No. 3

Ryan, R. M., \& Deci, E. L. (2000). Intrinsic and extrinsic motivations: classic definitions and new directions, Contemporary Educational Psychology, 25, 54-67. https://doi.org/10.1006/ceps.1999.1020

Swanson, R. A. (2005). The challenge of research in organization', in R. A. Swanson, \& Elwood F. H., III. (Eds.), Research in organizations: foundations and methods of inquiry (1st ed., pp.3-10). Berrett-Koehler Publishers, Inc.

Sweet, S. N., Fortier, M. S., Strachan, S. M., \& Blanchard, C. M. (2012). Integrating self-determination theory and self-efficacy theory in a physical activity context, Canadian Psychology, 53(4), 319-327. https://doi.org/10.1037/a0030280

Ulla, M. B. (2018). Benefits and challenges of doing research: Experiences from Philippine public school teachers, Issues in Educational Research, 28(3), 797-810. Retrieved from http://www.iier.org.au/iier28/ulla.pdf

UNESCO Institute for Statistics (2020). Global Investments in $R \& D$. Retrieved from http://uis.unesco.org/sites/default/files/documents/fs59-global-investments-rd-2020-en.pdf

Van de Ven, A. H. (2005). Advancing research in organizations through learning communities. In R. A. Swanson, \& Elwood F. Holton III (Eds.), Research in organizations: foundations and methods of inquiry (1st ed., pp. ix-xii). Berrett-Koehler Publishers, Inc

Wichian, S. N., Wongwanich, S., \& Bowarnkitiwong, S. (2009). Factors affecting research productivity of faculty members in government universities: lisrel and neural network analyses, Kasetsart Journal of Social Sciences, 30(1), 67-78. Retrieved from https://so04.tci-thaijo.org/index.php/kjss/article/view/246489/167454 


\section{Appendix 1}

\section{Self-Assessment Questionnaire of Employee's Readiness to Conduct Research}

Date:

Part 1: This part aims to assess the employee's readiness to produce research. Based on your level of readiness, you may be invited to participate in your organization's research activities.

Please, give yourself 5-10 minutes to answer the questions below using the scale (1 - Strongly disagree to 5 - Strongly agree).

\begin{tabular}{|c|c|c|c|c|c|c|}
\hline & Question & $\begin{array}{l}\text { Strongly } \\
\text { disagree }\end{array}$ & Disagree & $\begin{array}{l}\text { Not } \\
\text { Sure }\end{array}$ & Agree & $\begin{array}{c}\text { Strongly } \\
\text { agree }\end{array}$ \\
\hline 1 & $\begin{array}{l}\text { I am confident that I have basic research } \\
\text { knowledge and skills. }\end{array}$ & 1 & 2 & 3 & 4 & 5 \\
\hline 2 & $\begin{array}{l}\text { I can stand against all possible challenges } \\
\text { related to conducting research. }\end{array}$ & 1 & 2 & 3 & 4 & 5 \\
\hline 3 & $\begin{array}{l}\text { I can learn what is needed to conduct } \\
\text { research. }\end{array}$ & 1 & 2 & 3 & 4 & 5 \\
\hline 4 & $\begin{array}{l}\text { I believe that research provides new } \\
\text { solutions. }\end{array}$ & 1 & 2 & 3 & 4 & 5 \\
\hline 5 & I believe that research builds my credibility. & 1 & 2 & 3 & 4 & 5 \\
\hline 6 & I feel responsible for producing research. & 1 & 2 & 3 & 4 & 5 \\
\hline 7 & $\begin{array}{l}\text { I feel proud of participating in research } \\
\text { activities. }\end{array}$ & 1 & 2 & 3 & 4 & 5 \\
\hline 8 & I have the interest to reach new findings. & 1 & 2 & 3 & 4 & 5 \\
\hline 9 & $\begin{array}{l}\text { I am enthusiastic about participating in a } \\
\text { research project. }\end{array}$ & 1 & 2 & 3 & 4 & 5 \\
\hline 10 & $\begin{array}{l}\text { I master the skills of formulating research } \\
\text { problems and questions. }\end{array}$ & 1 & 2 & 3 & 4 & 5 \\
\hline 11 & $\begin{array}{l}\text { I master the skills of searching for } \\
\text { information online. }\end{array}$ & 1 & 2 & 3 & 4 & 5 \\
\hline 12 & I master the skills of academic writing. & 1 & 2 & 3 & 4 & 5 \\
\hline 13 & $\begin{array}{l}\text { I have basic knowledge of the various } \\
\text { research methodologies. }\end{array}$ & 1 & 2 & 3 & 4 & 5 \\
\hline 14 & I master the basic skills of analyzing data. & 1 & 2 & 3 & 4 & 5 \\
\hline 15 & I have previous research experience. & 1 & 2 & 3 & 4 & 5 \\
\hline 16 & I have a sense of academic independence. & 1 & 2 & 3 & 4 & 5 \\
\hline 17 & $\begin{array}{l}\text { I can develop my research knowledge and } \\
\text { skills alone. }\end{array}$ & 1 & 2 & 3 & 4 & 5 \\
\hline 18 & $\begin{array}{l}\text { I am willing to participate in long-run } \\
\text { research learning activities. }\end{array}$ & 1 & 2 & 3 & 4 & 5 \\
\hline 19 & I have the intention to join a research team. & 1 & 2 & 3 & 4 & 5 \\
\hline \multicolumn{2}{|c|}{ The total score } & & & & & \\
\hline
\end{tabular}




\section{Al Macrothink}

International Journal of Learning and Development

ISSN 2164-4063 2021, Vol. 11, No. 3

Part 2: Demographic Information

\begin{tabular}{|l|l|l|}
\hline 1. & Name: & \\
\hline 2. & Phone: & \\
\hline 3. & Email: & \\
\hline 4. & Gender: & \\
\hline 5. & Age: & \\
\hline 6. & Workplace: & \\
\hline 7. & Unit: & \\
\hline 8. & Position: & \\
\hline 9. & Education & \\
\hline 10. & Years of experience: & \\
\hline
\end{tabular}

Note. calculate the final score by summing the scores of all items. A total score $<50$ indicates low readiness, 50 to 65 indicates moderate readiness, and $>65$ indicates high readiness to produce research.

\section{Copyright Disclaimer}

Copyright for this article is retained by the author(s), with first publication rights granted to the journal.

This is an open-access article distributed under the terms and conditions of the Creative Commons Attribution license (http://creativecommons.org/licenses/by/4.0/). 